\title{
The E-F Hand Calcium-Binding Protein S100A4 Regulates the Proliferation, Survival and Differentiation Potential of Human Osteosarcoma Cells
}

\author{
Xian Chen ${ }^{\mathrm{a}}$ Gaurav Luther ${ }^{\mathrm{b}}$ Wenwen Zhang ${ }^{\mathrm{a}, \mathrm{b}}$ Guoxin Nan ${ }^{\mathrm{a}, \mathrm{b}}$ Eric R. Wagner ${ }^{\mathrm{b}}$ \\ Zhan Liao ${ }^{b, c}$ Ningning Wu $u^{a, b}$ Hongmei Zhang ${ }^{a, b}$ Ning Wang ${ }^{b, d}$ Sheng Wen ${ }^{a, b}$ \\ Yunfeng He $\mathrm{H}^{\mathrm{a}, \mathrm{b}}$ Fang Deng ${ }^{\mathrm{b}, \mathrm{d}}$ Junhui Zhang ${ }^{\mathrm{a}, \mathrm{b}}$ Di Wub Bosi Zhang ${ }^{\mathrm{b}}$ \\ Rex C. Haydon ${ }^{b}$ Lan Zhou a,b Hue H. Luu ${ }^{b}$ Tong-Chuan He
}

ainistry of Education Key Laboratory of Clinical Diagnostic Medicine and the Affiliated Hospitals of Chongqing Medical University, Chongqing, China; ${ }^{b}$ Molecular Oncology Laboratory, Department of Orthopaedic Surgery and Rehabilitation Medicine, The University of Chicago Medical Center, Chicago, IL, USA; 'Department of Orthopaedic Surgery, Xiang-Ya Hospital of Central South University, Changsha, China; ${ }^{d}$ Departments of Cell Biology and Oncology, Third Military Medical University, Chongqing, China

\section{Key Words}

Osteosarcoma - Bone tumors - S100A4 - Osteogenic differentiation - Soft tissue tumors • Proliferation $\cdot$ Apoptosis $\cdot$ Differentiation

\begin{abstract}
Background/Aims: Osteosarcoma (OS) is the most common primary bone malignancy in children and young adults. Molecular mechanisms underlying the pathogenesis of OS remain to be fully understood. Several members of the E-F hand calcium-binding S100 protein family are differentially expressed in human cancers. We previously showed that S100A6 is highly expressed in OS tumors. In this study, we investigated the role of S100A4 in regulating OS proliferation and osteogenic differentiation. Methods/Results: Endogenous S100 expression was examined by semi-quantitative PCR in human OS lines. Adenoviral vector-mediated overexpression and RNAi knockdown of S100A4 were used to assess S100A4's effects on cell proliferation, migration and invasion and osteogenic differentiation. Apoptosis was assessed by using anti-caspase-3 immunostaining and flow cytometry with annexin $V$ staining. Early osteogenic marker alkaline phosphatase (ALP) and late markers osteocalcin (OCN) and osteopontin (OPN) were assessed to determine the status of osteogenic differentiation. We found that S100A4 was elevated in metastatic MG63.2 cells. S100A4 knockdown inhibited cell proliferation, prolonged cell doubling time, and induced significant apoptosis. Silencing S100A4 expression in OS cells delayed cell wounding closure and diminished the numbers of migrated OS cells in transwell invasion assay. Furthermore, silencing S100A4 expression stimulated ALP


activity, as well as late markers OPN and OCN, in both OS cells and mesenchymal stem cells. Conclusion: Our results strongly suggest that S100A4 may promote OS tumor growth by regulating the cell cycle, reducing apoptosis, and inhibiting osteogenic differentiation. Thus, S100A4 may serve as a marker for tumorigenic potential, as well as a therapeutic target.

Copyright $\odot 2013$ S. Karger AG, Basel

\section{Introduction}

Osteosarcoma (OS) is the most common primary bone malignancy, characterized by resistance to chemotherapy and frequent relapses leading to poor overall prognosis [1-6]. Even with improved therapeutic interventions, many patients fail to achieve longterm disease free survival[5, 7]. This is in part secondary to the cytogenic modifications acquired by OS to develop resistance to chemotherapy [8]. Such cellular changes occur in many signaling pathways associated with tumor suppressor genes and oncogenes, such as p53 and $\mathrm{Rb}[2,4,9-11]$. While the degree to which these alterations are associated with OS has yet to be established, certain genetic alterations, such as hereditary retinoblastoma or Paget's disease of bone, increase the risk of developing OS $[12,13]$. Thus, there is a critical need not only to delineate the molecular underpinning of human osteosarcoma, but also to identify molecular targets for effective therapeutic interventions.

S100 protein family includes more than 20 small proteins that contain E-F hand calcium-binding motifs, and is mostly located on chromosome 1q21 [14-16], a chromosomal region with high frequencies of genetic alterations and rearrangements in human OS cells [2, $4,9-11]$. We recently found that S100A6 is highly expressed in OS tumors although its exact role in OS development remains to be fully elucidated $[17,18]$. Several of S100 proteins are up-regulated or differentially expressed in human tumors and exhibit tumor-promoting activities [14, 19-21]. While elevated S100A4 expression level has been reported in several types of human cancers and exhibit metastasis-promoting activities [19,22-26], detailed mechanisms underlying S100A4's role in regulating proliferation and metastasis of tumor cells remain to be fully elucidated. Thus, a further investigation into the role of S100A4 in OS is warranted.

Using our previously characterized metastatic OS line MG63.2 [27, 28] and the commonly-used aggressive OS line 143B [29], we investigate the role of S100A4 in regulating the proliferation, survival, and differentiation of OS cells. Our results indicate that S100A4 expression is significantly elevated in the metastatic MG63.2 cells. S100A4 knockdown inhibits cell proliferation, prolongs cell doubling time, and induces significant apoptosis. Silencing S100A4 expression in OS cells delays cell wounding closure and diminishes the numbers of migrated OS cells in transwell invasion assay. Furthermore, silencing S100A4 expression stimulates ALP activity, as well as the expression of late markers OPN and OCN, in both OS cells and mesenchymal stem cells. Thus, our results strongly suggest that S100A4 may promote OS tumor growth by regulating the cell cycle, reducing apoptosis, and inhibiting osteogenic differentiation. It is conceivable that S100A4 may serve as a marker for tumorigenic potential, as well as a therapeutic target for OS treatment.

\section{Materials and Methods}

Tissue culture

Human OS cell lines MG63 and 143B, and mouse mesenchymal stem cell line C3H10T1/2 were purchased from ATCC (Manassas, VA). We also used a highly tumorigenic and metastatic MG63.2 line as previously described [27, 28]. These cells were maintained in conditions as described [30-32]. Unless otherwise indicated, all chemicals were purchased from Sigma-Aldrich (St. Louis, MO) or Fisher Scientific (Pittsburgh, PA). 
Recombinant adenoviruses expressing S100A4, siS100A4 and RFP

Recombinant adenovirus expressing human S100A4 (Ad-S100A4) was created using AdEasy technology [32-36]. The siRNA target sites of human and mouse S100A4 mRNA were designed through the Thermo Scientific's siDesign online program, which allowed performing blast search of human and mouse databases, respectively, in order to minimize the off-target possibility. We designed three siRNA target sites for human and mouse S100A4, respectively. The three sites for human S100A4 include 5'-GCA AAG AGG GTG ACA AGT T-3', 5'-GGG ACA ACG AGG TGG ACT T-3', and 5'-GAT AAG CAG CCC AGG AAG A-3'. The three sites for mouse S100A4 were 5'- ACA ATG AAG CTC TGA AAT A-3', 5'-GCA AGA AGG AGC TGA AGG A-3', and 5'TGG ATG ATC TGG ACC GTA A-3'. The siRNA knockdown oligo cassettes for human and mouse S100A4 were cloned into a shuttle vector pSES [37], and the adenovirus pool (Ad-siS100A4 for human S100A4 siRNA pool, and Ad-simS100A4 siRNA pool) was generated using the AdEasy system as described [33, 36]. All PCR amplified fragments and cloned siRNA oligo cassettes were sequencing verified. Details are available upon request. Ad-S100A4 co-expresses GFP while Ad-siS100A4 co-expresses RFP in order to effectively monitor infection efficiency. An analogous adenovirus expressing RFP only (Ad-RFP) was used as a control [32-36].

RNA isolation and semi-quantitative RT-PCR (sqPCR)

Total RNA was isolated using TRIZOL Reagents (Invitrogen), and cDNA was generated via reverse transcriptase-PCR. The sqPCR was carried out as previously described [38-41]. The qPCR primer sequences are available upon request. All samples were normalized using the GADPH expression level.

\section{Western blot analysis for S100A4 expression and knockdown}

Western blot analysis was performed as described [31, 42]. Briefly, subconfluent 143B cells were infected with Ad-S100A4, Ad-siS100A4, or Ad-RFP. At 72h, cells were lyzed and subjected to SDS-PAGE and Western blot with an anti-S100A4 antibody (DAKO) and a secondary antibody conjugated with horseradish (Pierce, Rockford, IL). The presence of S100A4 protein was visualized with SuperSignal West Pico Chemiluminescent Substrate kit.

\section{Cell proliferation assay}

Cell proliferation assays were performed as described $[29,43,44]$. Briefly, subconfluent OS cells were infected with Ad-S100A4, Ad-siS100A4, or Ad-RFP. Cells were replated at 72 hours in 1\% FBS complete media. Cells were then collected by trypsinization at the indicated time points and viable cells were stained with Trypan Blue and counted. Each assay was done in triplicate.

\section{Cell wound healing/migration assay}

Wound healing migration assays were performed as described [28, 29, 31, 45, 46]. Subconfluent OS cells were infected with Ad-S100A4, Ad-siS100A4, or Ad-RFP for 16h and replated in 6-well cell culture plates. After $6 \mathrm{~h}$ an artificial scratch was made in the center of the cell monolayer using pipette tips. Bright field images of the three different fields were taken between $0 \mathrm{~h}$ and $36 \mathrm{~h}$ to assess cell migration across the gap. The assays were done in triplicate.

\section{Transwell cell invasion assay}

Transwell cell invasion assay was performed as described [27-29]. Subconfluent OS cells were infected with Ad-S100A4, Ad-siS100A4, or Ad-RFP and plated in the upper chambers pre-coated with matrigel. After $72 \mathrm{~h}$, the membranes containing the invading cells were fixed in $10 \%$ formalin, stained with hematoxylin, and mounted onto slides with Permount. Ten random and non-overlapping high power fields were counted per insert. The assays were performed in triplicate.

\section{Immunohistochemical (IHC) staining}

IHC staining was carried out as described [17, 47]. Briefly, subconfluent cells were infected with AdS100A4, Ad-siS100A4 or Ad-RFP. At the endpoint of assays, cells were fixed, permeabilized, and blocked with donkey serum. Cells were then probed with primary antibodies (caspase-3, OPN and OCN antibodies), followed by incubation with respective secondary antibody conjugated with horseradish peroxidase (Pierce). The protein of interested was visualized by 3,3'-diaminobenzidine (DAB) staining. Isotype or species-specific IgG, and minus-primary antibody were used as negative controls. 


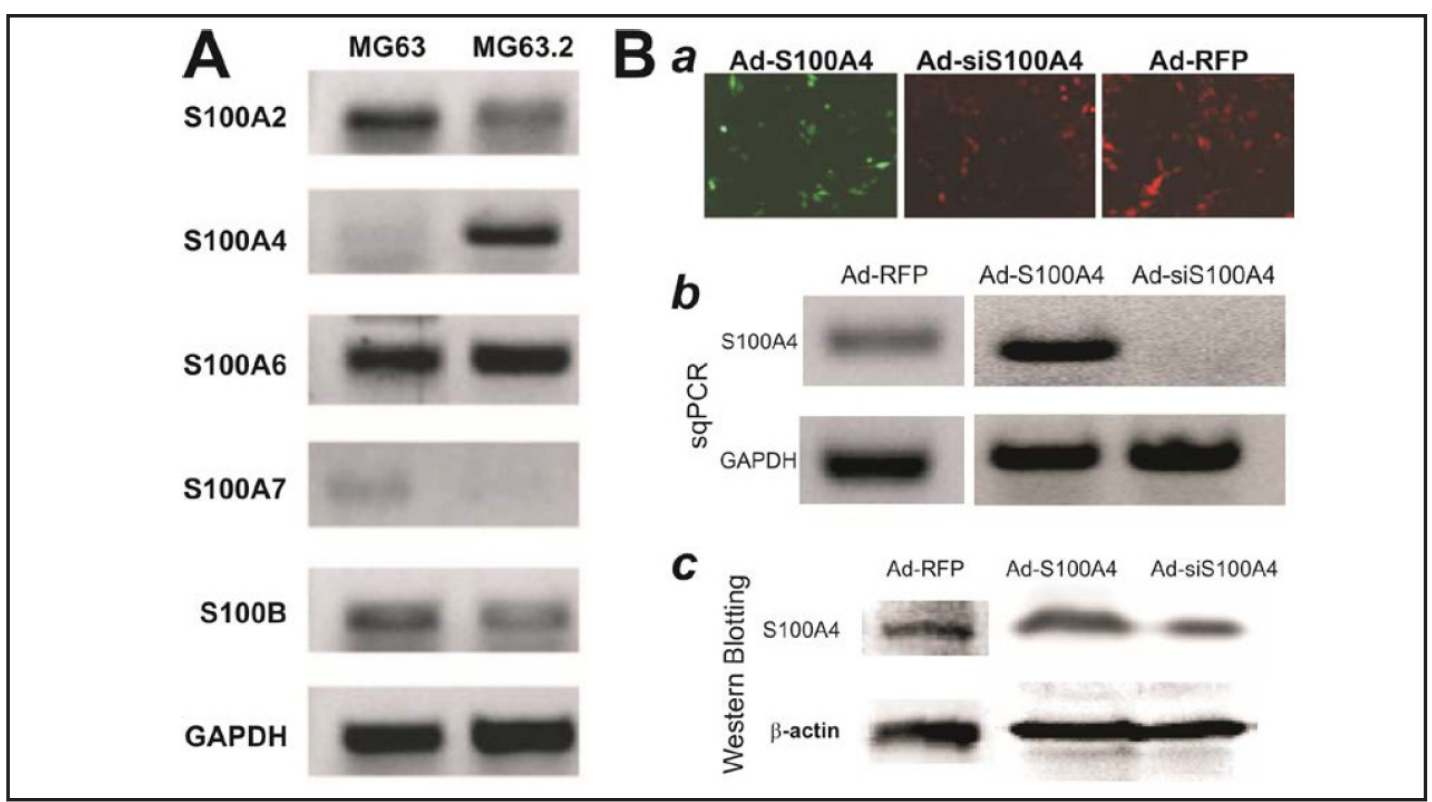

Fig. 1. Endogenous expression of S100A4 is elevated in metastatic OS cells. (A) Expression of five S100 genes in the highly metastatic MG63.2 and less metastatic MG63 cells. Total RNA was isolated from the OS lines and subjected to sqPCR analysis using primers for the specific S100 transcripts. The cDNA samples were normalized with GADPH expression level. (B) Generation of recombinant adenovirus overexpressing S100A4 or silencing S100A4 (siS100A4). Subconfluent 143B cells were infected with the same titer (MOI=5) of AdRFP, AdR-S100A4, or AdR-siS100A4. Fluorescence signal was recorded at 48h post infection (a). The adenovirus-mediated overexpression or knockdown of S100A4 was confirmed by sqPCR analysis (b) and Western blotting (c) in adenovirus-transduced 143B cells.

\section{Flow cytometry}

Subconfluent cells were treated as specified conditions. Cells were collected by trypsinization and fixed with 70\% ethanol, washed with PBS, and stained with propidium iodide and annexin V-GFP fusion protein. Cells were subjected to FACS analysis using the BD ${ }^{\mathrm{TM}}$ LSR II Flow Cytometer and the FlowJo software.

\section{Alkaline phosphatase assay}

ALP activity was assessed by a modified Great Escape SEAP Chemiluminescence assay (BD Clontech, Mountain View, CA) and/or histochemical staining assay (using a mixture of $0.1 \mathrm{mg} / \mathrm{ml}$ napthol AS-MX phosphate and $0.6 \mathrm{mg} / \mathrm{ml}$ Fast Blue BB salt) as described [31, 32, 34, 35, 38, 48-52]. For the chemilluminescence assays, each assay condition was performed in triplicate. The results were repeated in at least three independent experiments.

\section{Statistical analysis}

All quantitative experiments were performed in triplicate and/or repeated three times. Data were expressed as mean \pm SD. Statistical significances between treatment $v$ s. control were determined by oneway analysis of variance and the Student's $t$ test. A value of $p<0.05$ was considered statistically significant.

\section{Results}

Elevated S100A4 expression in the metastatic MG63.2 OS line

Several members of the S100 family play important roles in regulating tumorigenesis [14-16]. To test if S100 proteins play any role in OS growth and progression, we first detected the endogenous expression of S100A2, S100A4, S100A6, S100A7 and S100B in human OS line MG63 and its metastatic subline MG63.2 using semi-quantitative RT-PCR analysis. The 


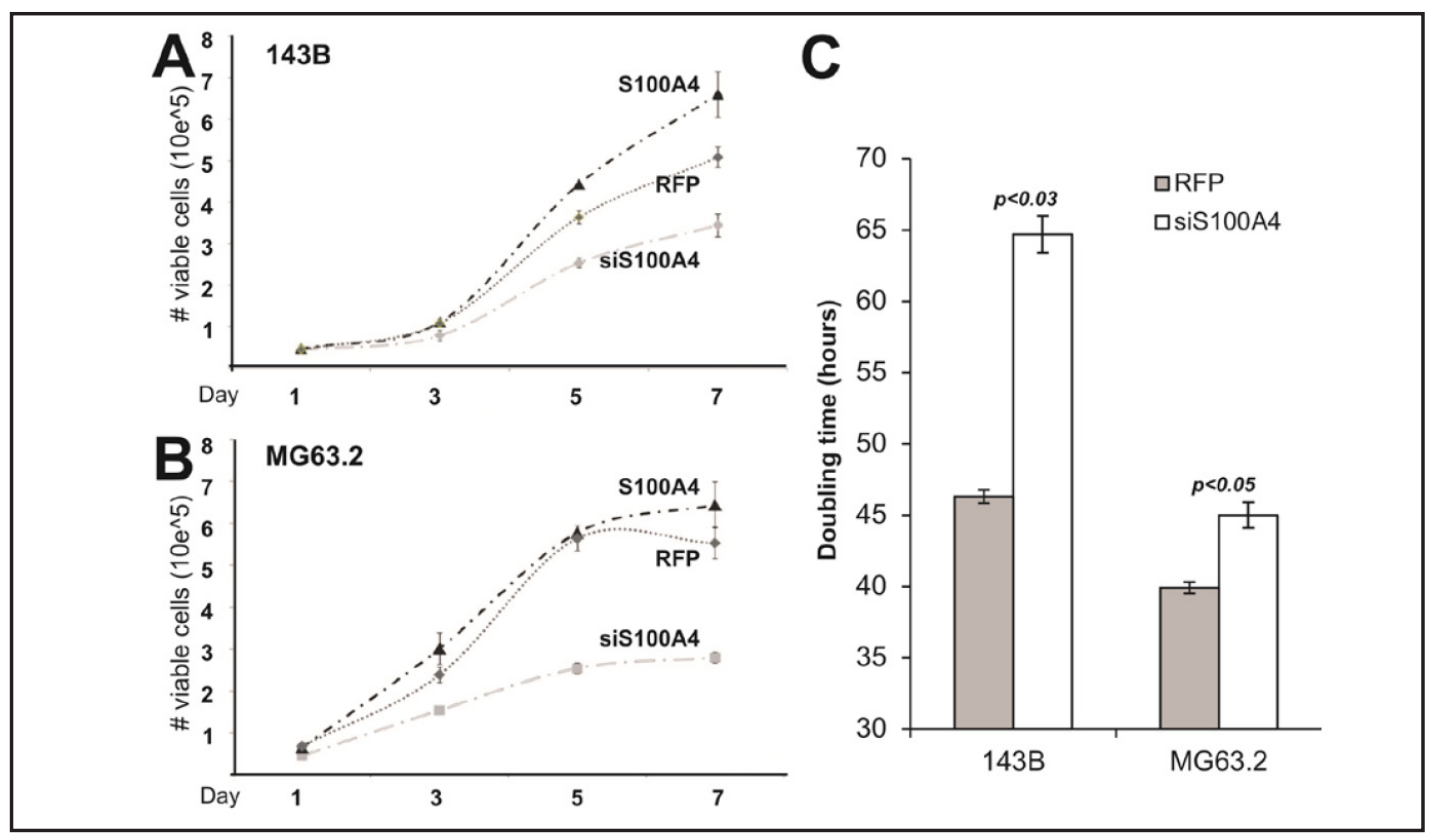

Fig. 2. Knockdown of S100A4 in OS cells inhibits cell proliferation. (A and B) Subconfluent 143B (A) and MG63.2 (B) cells were transduced with Ad-S100A4, Ad-siS100A4, or Ad-RFP control, and maintained in $10 \%$ FBS medium. Viable cells were stained with trypan blue and counted the indicated time points. (C) Silencing S100A4 prolongs the doubling time of OS cells. The cell doubling time was calculated using the Schwartz formula based the cell count data obtained from (A and B). Each assay condition was performed in triplicate.

MG63.2 line is a highly metastatic cell line established from its less metastatic parental MG63 line through serial passage in nude mice [27-29]. Except for S100A7, four of the examined S100 genes were expressed in MG63 and/or MG63.2 lines (Fig. 1A). However, only S100A4 expression was significantly elevated in MG63.2 cells when compared to that in MG63 cells, suggesting that high expression of S100A4 may be associated with OS tumor progression and metastasis. Consistent with our previous reports [17, 18], S100A6 expression was readily detected in OS cells.

Silencing S100A4 expression inhibits human OS cell proliferation

To further examine the functional role of S100A4 in OS tumorigenesis, we generated recombinant adenoviruses that express S100A4 (e.g., Ad-S100A4) and siRNA to knockdown human S100A4 expression (e.g., AdR-siS100A4), both of which co-express GFP or RFP as a marker to monitor infection efficiency and subsequent transgene expression. The adenoviral vectors were shown to transduce MG63.2 cells with high efficiency (Fig. 1B, panel a). The adenovirus-mediated overexpression of S100A4 or knockdown of S100A4 expression was further confirmed in adenoviral transduced 143B cells using sqPCR analysis (Fig. 1B, panel b) or Western blotting (Fig. 1B, panel c).

We next assessed the effect of exogenous S100A4 expression or silencing S100A4 expression on OS cell proliferation in $143 \mathrm{~B}$ cell line, which is also a commonly-used and aggressive human OS line. S100A4 overexpression increased the proliferation rate of 143B cells, with an increase in the number of cells over that of the RFP control starting day 3 $(\mathrm{p}<0.03)$, while silencing S100A4 expression significantly inhibited the proliferation rate of 143B cells $(\mathrm{p}<0.001)$ (Fig. 2A). A similar increase in proliferation, although to a lesser extent, was seen when S100A4 was overexpressed in MG63.2 cells $(\mathrm{p}<0.05)$ (Fig. 2B). However, S100A4 knockdown resulted a pronounced decrease in proliferation rate of MG63.2 cells $(\mathrm{p}<0.001)$ (Fig. 2B). The calculated doubling time (in hours) for S100A4, RFP, 


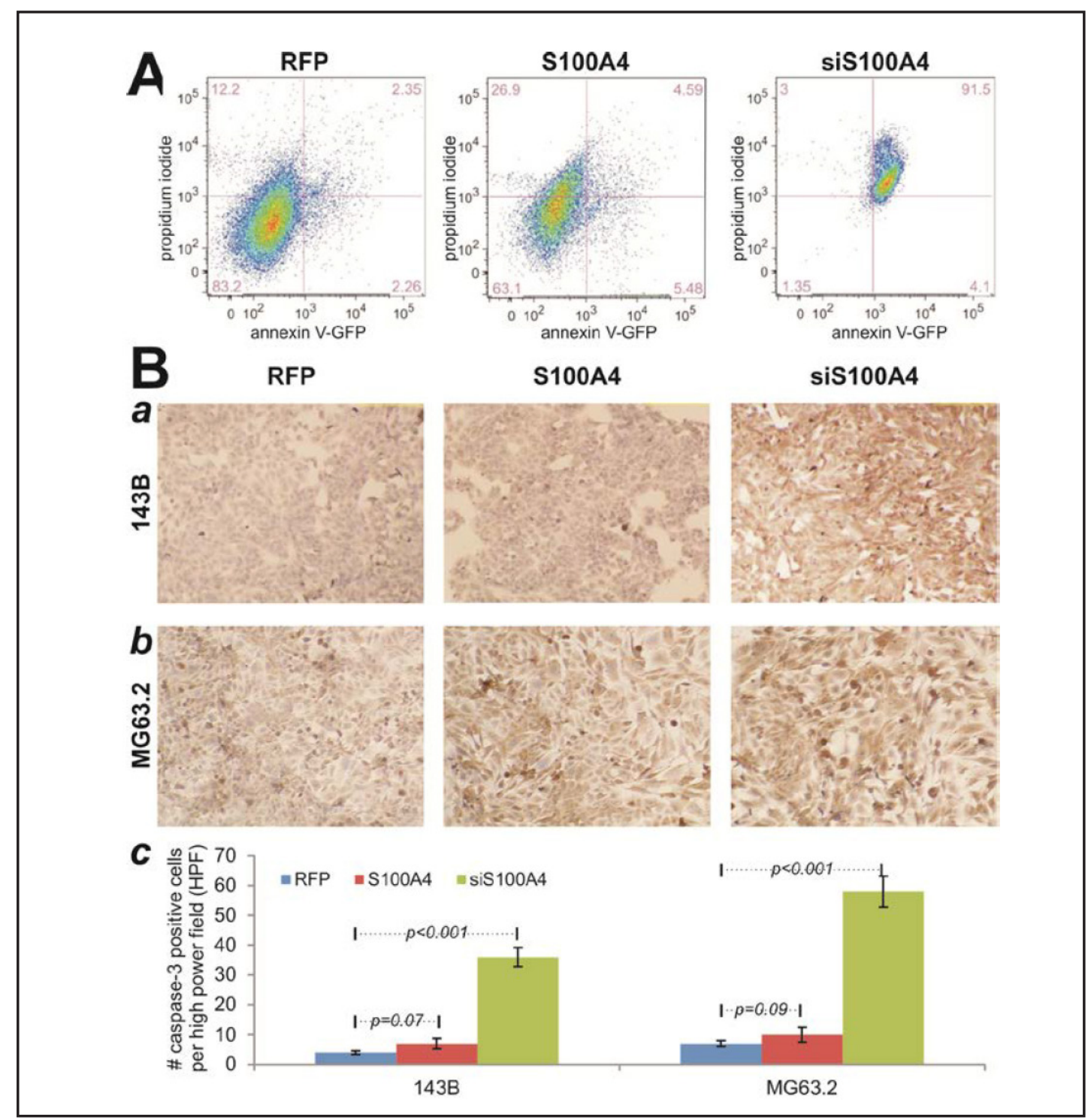

Fig. 3. Silencing S100A4 expression in OS cells promotes apoptosis. (A) FACS analysis of apoptosis. Subconfluent 143B cells were infected with AdRFP, AdR-S100A4, or AdR-siS100A4 for 36h. The cells were trypsinized, replated and maintained in 1\% FBS complete media, and collected $48 \mathrm{~h}$ later. The cells were fixed, stained with propidium iodide and annexin $\mathrm{V}$, and subjected to flow cytometry, followed by data analysis. (B) An elevation of caspase-3 expression in S100A4-silenced OS cells. Subconfluent 143B (a) and MG63.2 (b) cells were transduced with the indicated adenoviruses for $72 \mathrm{~h}$. Cells were fixed and subjected to immunohistochemical staining using caspase-3 antibody (Santa Cruz Biotechnology). (c) Average numbers of cleaved caspase- 3 positive cells were analyzed by counting positively stained cells from 20 random high power fields (HPFs, 200x) for each conditions. Isotype IgG and minus the primary antibody were used as negative controls (data not shown). Representative results are shown.

and siS100A4-transduced 143B cells were 38.5 $\pm 1.1,46.3 \pm 2.5$, and $64.7 \pm 3.5$, respectively (Fig. 2C). Accordingly, the doubling time for the MG63.2 cells transduced with RFP, S100A4, and siS100A4 were 39.9 $\pm 1.0,37.4 \pm 2.0$, and $45.0 \pm 2.3$, respectively (Fig. 2C). Taken together, the proliferation assay results indicate that silencing S100A4 expression significantly decreases the proliferation rate of OS cells while S100A4 overexpression can promote OS cell proliferation to certain degrees. 


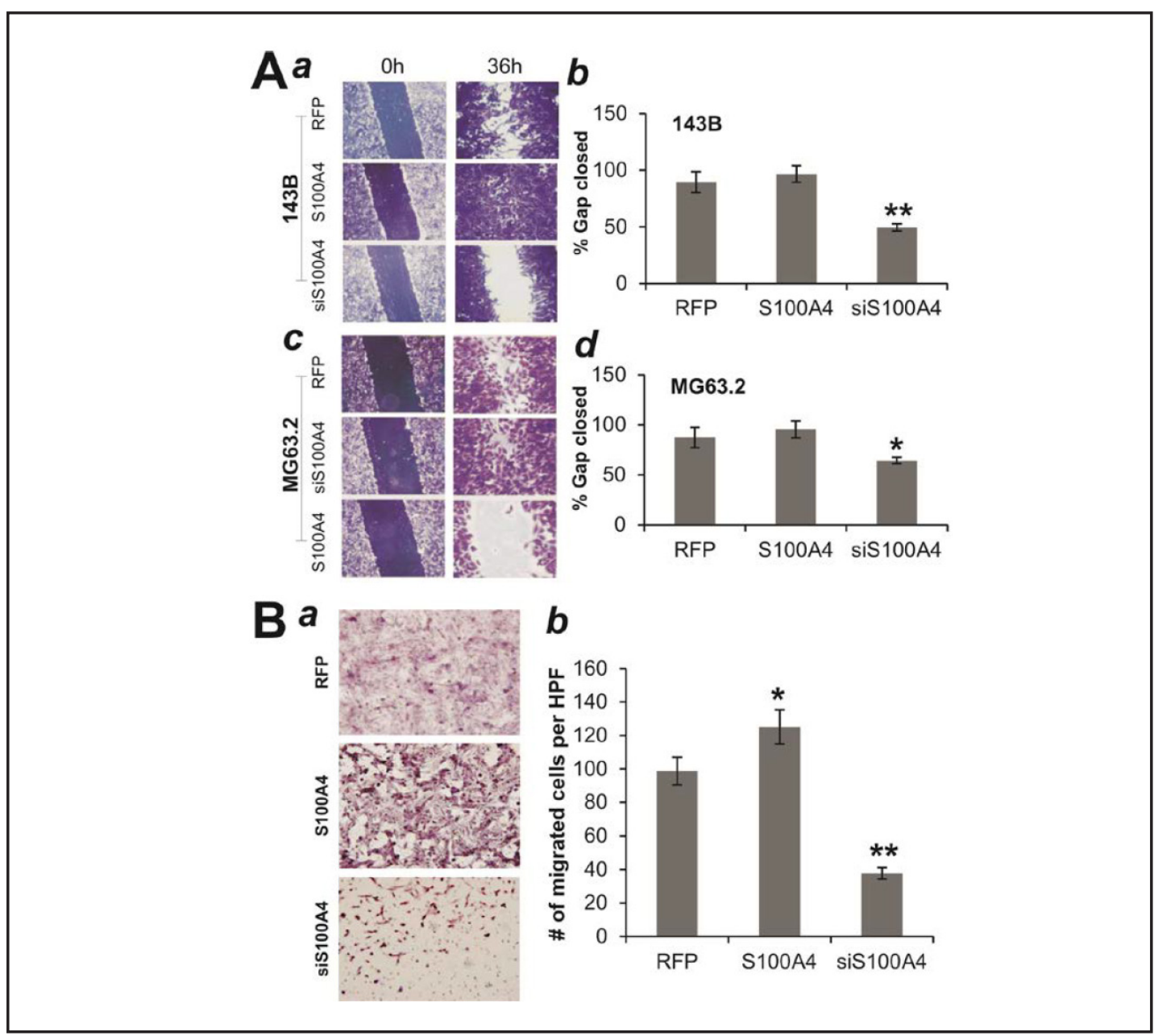

Fig. 4. Silencing S100A4 diminishes the migration and invasiveness features of OS cells. (A) Adenovirus vector-mediated knockdown of S100A4 in OS cells results in reduced cell wound healing and gap closure. Adenovirus transduced 143B (a) and MG63.2 (c) cells were plated in 1\% FBS media and subjected to an artificial scratch in the center of the cell monolayer with pipette tips. Bright field images were taken at $0 \mathrm{~h}$ and 36h (a and c). Quantification of cell migration was done by averaging the gap distances at least 3 randomly chosen points in each sample. Each assay conditions were done in triplicate. Average gap distance was calculated and graphed (b and d). Representative results are shown. (B) S100A4 promotes OS cell invasion. Subconfluent 143B cells were infected with Ad-S100A4, Ad-siS100A4, or Ad-RFP and plated in the upper chamber of matrigel-coated transwells. After $72 \mathrm{~h}$, the membranes containing the invading cells were fixed, stained with hematoxylin, mounted onto slides, and examined under a microscope (a). The numbers of invading cells were counted in at least 10 random non-overlapping high power fields (HPF) from each transwell sample and quantitatively analyzed (b). Representative images are shown (a). “*” $p<0.05$; “**”, $p<0.001$.

\section{Knockdown of S100A4 expression induces OS cell apoptosis}

We sought to examine the effects of S100A4 on cell cycle and apoptosis in OS cells. When 143B cells were transduced with AdRFP, AdR-S100A4, or AdR-siS100A4 and subjected to FACS analysis with annexin V labeling, the cells were sorted into 3 phases (viable, early apoptotic, and late apoptotic). Consistent with the results from the proliferation assays, significantly lower numbers of S100A4-transduced cells were in the early and late phases of apoptosis (5.4\% and $4.5 \%$, respectively) when compared to the siS100A4 group $(4.1 \%$ and $91.5 \%$, respectively, p<0.001) (Fig. 3A). Furthermore, immunohistochemical staining with caspase-3 antibody indicates that S100A4 knockdown in both 143B and MG63.2 cells caused 
strong positive staining of the cleaved caspase-3 (Fig. 3B, panels a \& b). The average of cleaved caspase-3 positive cells was significantly higher in S100A4 knockdown cells $(p<0.001)$ (Fig. 3B, panel c). Taken together, these results suggest that S100A4 may support the survival of OS cells and that knockdown of S100A4 expression could predispose OS cells to apoptosis.

\section{S100A4 promotes OS cell migration and invasion}

The ability of tumor cells to migrate and invade is an important indicator of cell aggressiveness and metastatic potential. We assessed the effect of S100A4 on OS cell migration and transwell invasion as described [27-29]. Briefly, an artificial scratch was made in a confluent monolayer of adenoviral vector- transduced OS cells. The ability of the cells to close the gap was measured qualitatively and quantitatively in 143B cells (Fig 4A, panels a \& b). Knockdown of S100A4 expression significantly inhibited the migration of 143B cells (Fig 4A, panel a). When the gap closure was quantified, the S100A4, siS100A4, and RFP groups resulted in 99\%, 49\%, and 86\% closure, respectively (p<0.001) (Fig 4A, panel b). Similar results were obtained for MG63.2 cells (Fig 4A, panels c \& d). Overexpression of S100A4 promoted cell migration while inhibition of S100A4 significantly inhibited migration (Fig 4A, panel c). Quantitative gap closure for the S100A4 siS100A4, and RFP groups was approximately $94 \%, 63 \%$, and $87 \%$, respectively ( $\mathrm{p}<0.05$ ) (Fig 4A, panels c \& d).

The invasiveness of OS cells was also assessed using a previously described transwell invasion assay [27-29]. Subconfluent 143B cells were infected with Ad-S100A4, AdsiS100A4, or Ad-RFP and plated in the upper chamber of matrigel-coated transwells for $72 \mathrm{~h}$. We found that S100A4 overexpression led to a significantly more migrated cells than that of the RFP control group, while silencing S100A4 expression in OS cells yielded the least invading cells among the three groups (Fig. 4B, panel a). When the numbers of migrated cells were quantified, we found that knockdown of S100A4 significantly inhibited cell invasion $(p<0.001)$, while overexpression of S100A4 resulted in significantly greater cell invasion compared to the RFP control $(\mathrm{p}<0.05)$ (Fig. 4B, panel b). Similar results were obtained for MG63.2 cells in the transwell migration assay (data not shown). Taken together, these results strongly suggest that S100A4 may play an important role in regulating OS cell migration and invasiveness.

\section{Knockdown of S100A4 induces osteogenic differentiation}

We and others have demonstrated that osteosarcoma development may be in part caused by differentiation defects, in which mesenchymal stem cells (MSCs) fail to undergo terminal osteogenic differentiation [2, 4, 31, 53]. Thus, we tested the effects of S100A4 overexpression and knockdown on osteogenic differentiation of OS cells and mesenchymal stem cells (MSCs). When MG63.2 OS cells were transduced with Ad-RFP, Ad-S100A4 and AdsiS100A4 and early osteogenic marker alkaline phosphatase (ALP) activity was measured at days 3 and 5, we found that knockdown of S100A4 significantly increased ALP activity when compared with RFP control group ( $p<0.001$ ) (Fig. 5A). We further transduced the MSC line C3H10T1/2 cells with Ad-RFP, Ad-S100A4, and AdR-siS100A4, and found that S100A4 knockdown induced a significant increase in ALP activity at day 7 (Fig. 5B). In both OS and MSC cells, S100A4 overexpression did not induce any significant changes in ALP activity when compared with that of the RFP control (Fig. 5B). Lastly, we examined the effects of S100A4 expression on the late osteogenic markers osteopontin (OPN) and osteocalcin $(\mathrm{OCN})$. Consistent with the results obtained in ALP assays, knockdown of S100A4 expression in MG63.2 cells resulted in a significant increase in the expression of OPN (Fig. 5C, panel a) and OCN (Fig. 5C, panel b), while S100A4 overexpression and RFP expression resulted in minimal staining. Similar results were obtained in 143B and C3H10T1/2 cells (data not shown). These results suggest that S100A4 may play an important role in regulating the intricate balance between proliferation and differentiation of osteoblast progenitors and its pro-tumorigenic effects may be a result of shifting this intrinsic cellular balance towards cell proliferation during osteosarcoma development and progression. 
Fig. 5. Knockdown of S100A4 induces osteogenic differentiation. (A and B) The effect of S100A4 knockdown on early osteogenic marker alkaline phosphatase (ALP) activity. Subconfluent MG63.2 (A) and mesenchymal stem line C3H10T1/2 (B) cells were transduced with Ad-RFP, AdR-S100A4, or AdR-siS100A4. ALP activity was measured at the indicated time points. Each assay was performed in triplicate. “**”, $p<0.001$. (C) The effect of S100A4 knockdown on late osteogenic markers osteopontin (OPN) and osteocalcin (OCN). Subconfluent MG63.2 cells were transduced with AdRFP, AdR-S100A4, or AdRsiS100A4 for 7 days. Cells were fixed and subjected to immunohistochemical staining with anti-OPN (a) and anti-OCN (b) antibodies (Santa Cruz Biotechnology). Isotype IgG and minus the primary antibody were used as negative controls (data not shown). Representative results are shown.

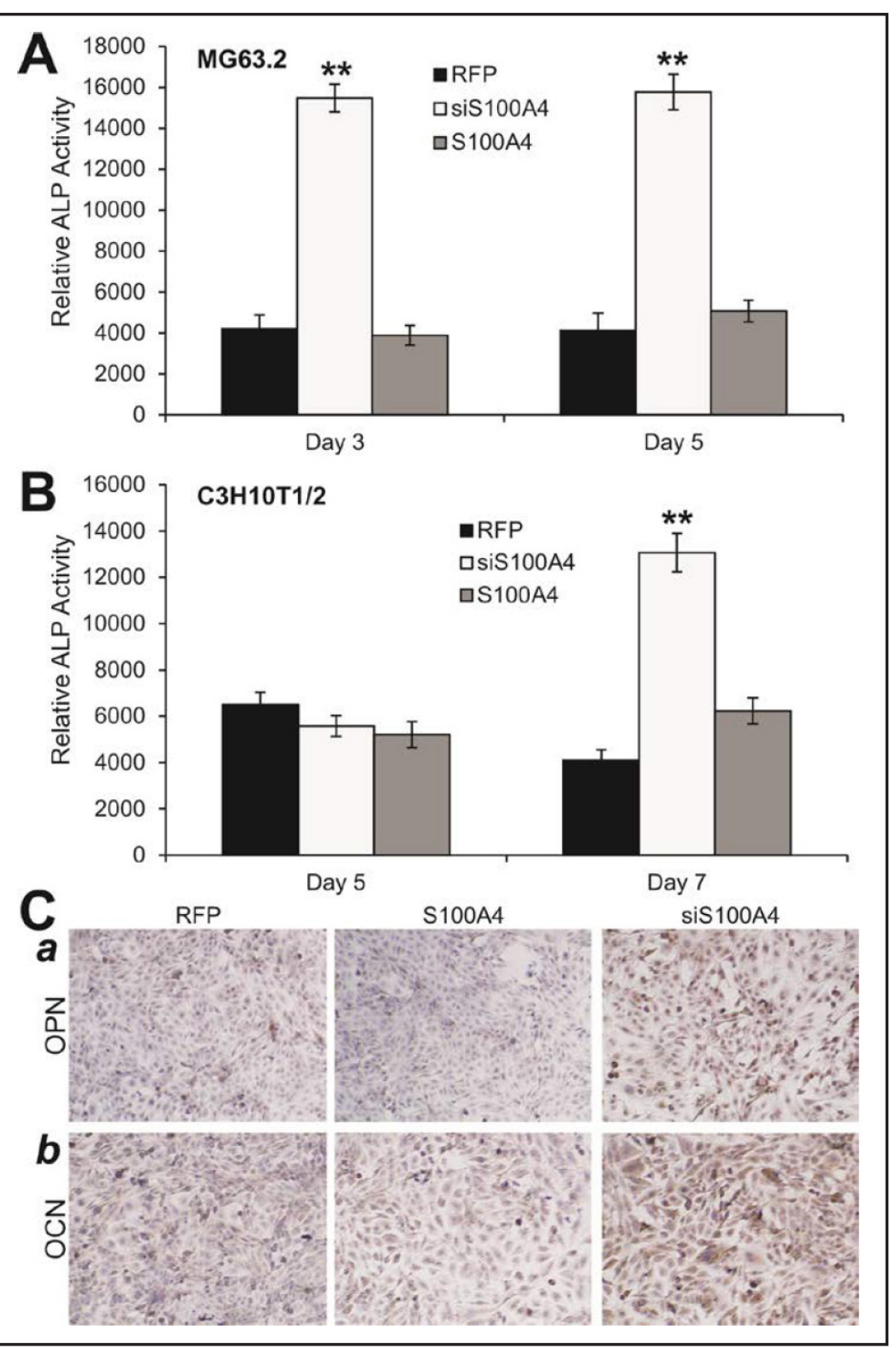

\section{Discussion}

The S100 protein family has been identified as a critical part of tumorigenesis in a variety of tissues $[15,21,54,55]$. Here we demonstrate that S100A4 expression is elevated in the highly metastatic MG63.2 cells when compared to the less MG63 parental line. We have shown that S100A4 overexpression promotes cell proliferation, cell migration and cell invasion, which may be in part mediated by S100A4's ability to regulate cell cycle and provide pro-survival and anti-apoptotic phenotypes in OS cells. Knockdown of S100A4 expression in OS cells enhances the expression of apoptotic marker, the cleaved caspase-3. Furthermore, we have shown that knockdown of S100A4 expression leads to an increase in both early and late osteogenic markers in OS cells as well as in MSCs, suggesting that S100A4 may play an important role in regulating the intricate balance between proliferation and differentiation of osteoblast progenitors and possibly OS cells.

S100A4 plays a crucial role in the metastatic conversion of various human cancers [22]. S100A4 binds to calcium as a dimer, which induces a conformational change and 
enables binding to its target proteins [55]. S100 proteins have been shown to modulate cell proliferation by targeting proteins critical to cell cycle regulation [54, 56, 57]. Our results indicate that $\mathrm{S} 100 \mathrm{~A} 4$ overexpression not only induces cell proliferation, but also has an inhibitory effect on apoptotic cascade. A possible explanation may lie in the ability of S100A4 to bind p53, a regulator of the cell cycle, DNA repair, and apoptosis. S100A4 binds p53 in a calcium dependent manner through dimerization and promotes p53 degradation [57-59]. Furthermore, S100A4 can interfere with the phosphorylation of p53, preventing cells from undergoing apoptosis $[23,57,58]$. Conversely, the decreased survival observed in OS cells with S100A4 knockdown may be due to the effect of S100A4 on apoptosis. Multiple cytogenetic abnormalities have been described in OS, including mutations in $p 53$ and $R b$, and activations of oncogenes such as $M y c[2,9,11]$. Thus, the ability of S100A4 to bind and modulate the pathways associated with $\mathrm{p} 53, \mathrm{Rb}$, and/or other oncogenes may explain the decrease in tumorigenic conversion upon S100A4 knockdown in OS cells.

The ability of primary tumor cells to metastasize and grow at sites distant from the primary tumor requires phenotypic conversion, including the ability to invade through basement membrane and migrate through the extracellular matrix. Invasion and migration often necessitate the primary tumor cells to increase motility and express proteins necessary for basement membrane invasion, such as matrix metalloproteinases (MMPs). Along these lines, we find that S100A4 increases the migratory and invasive abilities of OS cells. It has been reported that $\mathrm{S} 100 \mathrm{~A} 4$ interacts with non-muscle myosin II and promotes disassembly of fibers, thereby increasing the motility of cells [26, 60-62]. Furthermore, S100A4 has been shown to increase the expression of MMPs in certain cancers [26, 60-62]. Thus, it is likely that S100A4 may lead to increased tumor migration, invasion and metastasis in OS cells by regulating these proteins.

Osteogenic differentiation requires a delicate balance between proliferation and differentiation of MSCs [63-66]. We have demonstrated that disruptions in this balance lead to a malignant transformation $[4,53,67]$. It is conceivable that augmentation of proliferation or inhibition of differentiation would promote tumorigenic transformation seen in OS. It has been reported that MDM2-p53 pathway regulates osteogenic differentiation [68]. The role of S100A4 in osteogenic differentiation may at least in part explain the pro-survival phenotype in OS cells. We find that S100A4 knockdown in mesenchymal stem cells promotes differentiation and decreased cellular proliferation. Furthermore, we have shown that S100A4 knockdown in human OS cells promotes the expression of osteopontin and osteocalcin, both of which are markers of terminal osteoblast differentiation. It is possible that S100A4 exhibits a pro-tumorigenic phenotype by preventing terminal osteoblastic differentiation, inhibiting apoptosis, and promoting cell proliferation.

In summary, our results suggest that S100A4 may be an important regulator in the tumorigenesis associated with OS. It is conceivable that S100A4 may be further explored as a potential marker for OS tumorigenic potential, as well as a therapeutic target.

\section{Conflict of Interest}

The authors declare no conflict of interest.

\section{Acknowledgements}

The reported work was supported in part by research grant from the National Institutes of Health (CA106569, AT004418, AR50142, and AR054381 to TCH, RCH and HHL), and the Ministry of Science and Technology of China (\#2011CB707900 to TCH and LZ). 


\section{References}

1 Davis AM, Bell RS, Goodwin PJ: Prognostic factors in osteosarcoma: A critical review. J Clin Oncol 1994;12:423-431.

2 Tang N, Song WX, Luo J, Haydon RC, He TC: Osteosarcoma development and stem cell differentiation. Clin Orthop Relat Res 2008;466:2114-2130.

-3 Hayden JB, Hoang BH: Osteosarcoma: Basic science and clinical implications. Orthop Clin North Am 2006;37:1-7.

4 Haydon RC, Luu HH, He TC: Osteosarcoma and osteoblastic differentiation: A new perspective on oncogenesis. Clin Orthop Relat Res 2007;454:237-246.

5 Marina N, Gebhardt M, Teot L, Gorlick R: Biology and therapeutic advances for pediatric osteosarcoma. Oncologist 2004;9:422-441.

6 Murphey MD, Robbin MR, McRae GA, Flemming DJ, Temple HT, Kransdorf MJ: The many faces of osteosarcoma. Radiographics 1997;17:1205-1231.

7 Meyers PA, Gorlick R: Osteosarcoma. Pediatr Clin North Am 1997;44:973-989.

8 Chou AJ, Gorlick R: Chemotherapy resistance in osteosarcoma: Current challenges and future directions. Expert Rev Anticancer Ther 2006;6:1075-1085.

-9 Horowitz JM, Park SH, Bogenmann E, Cheng JC, Yandell DW, Kaye FJ, Minna JD, Dryja TP, Weinberg RA: Frequent inactivation of the retinoblastoma anti-oncogene is restricted to a subset of human tumor cells. Proc Nat Acad Sci USA 1990;87:2775-2779.

10 Helman LJ, Meltzer P: Mechanisms of sarcoma development. Nat Rev Cancer 2003;3:685-694.

11 Sandberg AA, Bridge JA: Updates on the cytogenetics and molecular genetics of bone and soft tissue tumors: Osteosarcoma and related tumors. Cancer Genet Cytogenet 2003;145:1-30.

12 Draper GJ, Sanders BM, Kingston JE: Second primary neoplasms in patients with retinoblastoma. Br J Cancer 1986;53:661-671.

-13 Arndt CA, Crist WM: Common musculoskeletal tumors of childhood and adolescence. N Engl J Med 1999;341:342-352.

14 Emberley ED, Murphy LC, Watson PH: S100 proteins and their influence on pro-survival pathways in cancer. Biochem Cell Biol 2004;82:508-515.

15 Schafer BW, Heizmann CW: The s100 family of ef-hand calcium-binding proteins: Functions and pathology. Trends Biochem Sci 1996;21:134-140.

16 Cmoch A, Groves P, Palczewska M, Pikula S: S100a proteins in propagation of a calcium signal in norm and pathology. Postepy Biochem 2012;58:429-436.

17 Luu HH, Zhou L, Haydon RC, Deyrup AT, Montag AG, Huo D, Heck R, Heizmann CW, Peabody TD, Simon MA, He TC: Increased expression of s100a6 is associated with decreased metastasis and inhibition of cell migration and anchorage independent growth in human osteosarcoma. Cancer Lett 2005;229:135-148.

18 Luo X, Sharff KA, Chen J, He TC, Luu HH: S100a6 expression and function in human osteosarcoma. Clin Orthop Relat Res 2008;466:2060-2070.

19 Salama I, Malone PS, Mihaimeed F, Jones JL: A review of the s100 proteins in cancer. Eur J Surg Oncol 2008;34:357-364.

20 Lukanidin E, Sleeman JP: Building the niche: The role of the s100 proteins in metastatic growth. Semin Cancer Biol 2012;22:216-225.

-21 Lesniak W, Filipek A: $\mathrm{Ca}^{2+}$-dependent interaction of calcyclin with membrane. Biochem Biophys Res Commun 1996;220:269-273.

-22 Mathisen B, Lindstad RI, Hansen J, El-Gewely SA, Maelandsmo GM, Hovig E, Fodstad O, Loennechen T, Winberg JO: S100a4 regulates membrane induced activation of matrix metalloproteinase- 2 in osteosarcoma cells. Clin Exp Metastasis 2003;20:701-711.

23 Sherbet GV: Metastasis promoter s100a4 is a potentially valuable molecular target for cancer therapy. Cancer Lett 2009;280:15-30.

24 Dukhanina EA, Kabanova OD, Lukyanova TI, Shatalov YV, Yashin DV, Romanova EA, Gnuchev NV, Galkin AV, Georgiev GP, Sashchenko LP: Opposite roles of metastasin (s100a4) in two potentially tumoricidal mechanisms involving human lymphocyte protein tag7 and hsp70. Proc Nat Acad Sci USA 2009;106:1396313967. 
25 Dukhanina EA, Yashin DV, Galkin AV, Sashchenko LP: Unexpected deeds of familiar proteins: Interplay of hsp70, pgrp-s/tag7 and s100a4/mts1 in host vs. Cancer combat. Cell Cycle 2010;9:676-682.

-26 Tarabykina S, Griffiths TR, Tulchinsky E, Mellon JK, Bronstein IB, Kriajevska M: Metastasis-associated protein s100a4: Spotlight on its role in cell migration. Curr Cancer Drug Targets 2007;7:217-228.

27 Su Y, Luo X, He BC, Wang Y, Chen L, Zuo GW, Liu B, Bi Y, Huang J, Zhu GH, He Y, Kang Q, Luo J, Shen J, Chen J, Jin X, Haydon RC, He TC, Luu HH: Establishment and characterization of a new highly metastatic human osteosarcoma cell line. Clin Exp Metastasis 2009;26:599-610.

28 Su Y, Wagner ER, Luo Q, Huang J, Chen L, He BC, Zuo GW, Shi Q, Zhang BQ, Zhu G, Bi Y, Luo J, Luo X, Kim SH, Shen J, Rastegar F, Huang E, Gao Y, Gao JL, Yang K, Wietholt C, Li M, Qin J, Haydon RC, He TC, Luu $\mathrm{HH}$ : Insulin-like growth factor binding protein 5 suppresses tumor growth and metastasis of human osteosarcoma. Oncogene 2011;30:3907-3917.

29 Luu HH, Kang Q Park JK, Si W, Luo Q, Jiang W, Yin H, Montag AG, Simon MA, Peabody TD, Haydon RC, Rinker-Schaeffer CW, He TC: An orthotopic model of human osteosarcoma growth and spontaneous pulmonary metastasis. Clin Exp Metastasis 2005;22:319-329.

-30 Haydon RC, Deyrup A, Ishikawa A, Heck R, Jiang W, Zhou L, Feng T, King D, Cheng H, Breyer B, Peabody T, Simon MA, Montag AG, He TC: Cytoplasmic and/or nuclear accumulation of the beta-catenin protein is a frequent event in human osteosarcoma. Int J Cancer 2002;102:338-342.

31 Luo X, Chen J, Song WX, Tang N, Luo J, Deng ZL, Sharff KA, He G, Bi Y, He BC, Bennett E, Huang J, Kang Q, Jiang W, Su Y, Zhu GH, Yin H, He Y, Wang Y, Souris JS, Chen L, Zuo GW, Montag AG, Reid RR, Haydon RC, Luu $\mathrm{HH}, \mathrm{He} \mathrm{TC}$ : Osteogenic bmps promote tumor growth of human osteosarcomas that harbor differentiation defects. Lab Invest 2008;88:1264-1277.

32 Cheng H, Jiang W, Phillips FM, Haydon RC, Peng Y, Zhou L, Luu HH, An N, Breyer B, Vanichakarn P, Szatkowski JP, Park JY, He TC: Osteogenic activity of the fourteen types of human bone morphogenetic proteins (bmps). J Bone Joint Surg Am 2003;85-A:1544-1552.

-33 He TC, Zhou S, da Costa LT, Yu J, Kinzler KW, Vogelstein B: A simplified system for generating recombinant adenoviruses. Proc Nat Acad Sci USA1998;95:2509-2514.

-34 Kang Q Song WX, Luo Q, Tang N, Luo J, Luo X, Chen J, Bi Y, He BC, Park JK, Jiang W, Tang Y, Huang J, Su Y, Zhu GH, He Y, Yin H, Hu Z, Wang Y, Chen L, Zuo GW, Pan X, Shen J, Vokes T, Reid RR, Haydon RC, Luu HH, He TC: A comprehensive analysis of the dual roles of bmps in regulating adipogenic and osteogenic differentiation of mesenchymal progenitor cells. Stem Cells Dev 2009;18:545-559.

-35 Kang Q Sun MH, Cheng H, Peng Y, Montag AG, Deyrup AT, Jiang W, Luu HH, Luo J, Szatkowski JP, Vanichakarn P, Park JY, Li Y, Haydon RC, He TC: Characterization of the distinct orthotopic bone-forming activity of 14 bmps using recombinant adenovirus-mediated gene delivery. Gene Ther 2004;11:1312-1320.

-36 Luo J, Deng ZL, Luo X, Tang N, Song WX, Chen J, Sharff KA, Luu HH, Haydon RC, Kinzler KW, Vogelstein B, He TC: A protocol for rapid generation of recombinant adenoviruses using the adeasy system. Nat Protoc 2007;2:1236-1247.

-37 Luo Q, Kang Q, Song WX, Luu HH, Luo X, An N, Luo J, Deng ZL, Jiang W, Yin H, Chen J, Sharff KA, Tang N, Bennett E, Haydon RC, He TC: Selection and validation of optimal sirna target sites for rnai-mediated gene silencing. Gene 2007;395:160-169.

-38 Sharff KA, Song WX, Luo X, Tang N, Luo J, Chen J, Bi Y, He BC, Huang J, Li X, Jiang W, Zhu GH, Su Y, He Y, Shen J, Wang Y, Chen L, Zuo GW, Liu B, Pan X, Reid RR, Luu HH, Haydon RC, He TC: Hey1 basic helix-loop-helix protein plays an important role in mediating bmp9-induced osteogenic differentiation of mesenchymal progenitor cells. J Biol Chem 2009;284:649-659.

-39 Hu N, Jiang D, Huang E, Liu X, Li R, Liang X, Kim SH, Chen X, Gao JL, Zhang H, Zhang W, Kong YH, Zhang J, Wang J, Shui W, Luo X, Liu B, Cui J, Rogers MR, Shen J, Zhao C, Wang N, Wu N, Luu HH, Haydon RC, He TC, Huang W: Bmp9-regulated angiogenic signaling plays an important role in the osteogenic differentiation of mesenchymal progenitor cells. J Cell Sci 2013;126:532-541.

40 Huang E, Bi Y, Jiang W, Luo X, Yang K, Gao JL, Gao Y, Luo Q, Shi Q Kim SH, Liu X, Li M, Hu N, Liu H, Cui J, Zhang W, Li R, Chen X, Shen J, Kong Y, Zhang J, Wang J, Luo J, He BC, Wang H, Reid RR, Luu HH, Haydon RC, Yang L, He TC: Conditionally immortalized mouse embryonic fibroblasts retain proliferative activity without compromising multipotent differentiation potential. PloS One 2012;7:e32428. 
41 Huang E, Zhu G, Jiang W, Yang K, Gao Y, Luo Q, Gao JL, Kim SH, Liu X, Li M, Shi Q, Hu N, Wang L, Liu H, Cui J, Zhang W, Li R, Chen X, Kong YH, Zhang J, Wang J, Shen J, Bi Y, Statz J, He BC, Luo J, Wang H, Xiong F, Luu HH, Haydon RC, Yang L, He TC: Growth hormone synergizes with bmp9 in osteogenic differentiation by activating the jak/stat/igf1 pathway in murine multilineage cells. J Bone Miner Res 2012;27:1566-1575.

42 Luo J, Tang M, Huang J, He BC, Gao JL, Chen L, Zuo GW, Zhang W, Luo Q, Shi Q, Zhang BQ, Bi Y, Luo X, Jiang W, Su Y, Shen J, Kim SH, Huang E, Gao Y, Zhou JZ, Yang K, Luu HH, Pan X, Haydon RC, Deng ZL, He TC: Tgfbeta/ bmp type i receptors alk1 and alk2 are essential for bmp9-induced osteogenic signaling in mesenchymal stem cells. J Biol Chem 2010;285:29588-29598.

43 He BC, Chen L, Zuo GW, Zhang W, Bi Y, Huang J, Wang Y, Jiang W, Luo Q, Shi Q, Zhang BQ Liu B, Lei X, Luo J, Luo X, Wagner ER, Kim SH, He CJ, Hu Y, Shen J, Zhou Q, Rastegar F, Deng ZL, Luu HH, He TC, Haydon RC: Synergistic antitumor effect of the activated ppargamma and retinoid receptors on human osteosarcoma. Clin Cancer Res 2010;16:2235-2245.

-44 He BC, Gao JL, Zhang BQ Luo Q, Shi Q Kim SH, Huang E, Gao Y, Yang K, Wagner ER, Wang L, Tang N, Luo J, Liu X, Li M, Bi Y, Shen J, Luther G, Hu N, Zhou Q, Luu HH, Haydon RC, Zhao Y, He TC: Tetrandrine inhibits wnt/beta-catenin signaling and suppresses tumor growth of human colorectal cancer. Mol Pharmacol 2011;79:211-219.

45 Luther GA, Lamplot J, Chen X, Rames R, Wagner ER, Liu X, Parekh A, Huang E, Kim SH, Shen J, Haydon RC, He TC, Luu HH: Igfbp5 domains exert distinct inhibitory effects on the tumorigenicity and metastasis of human osteosarcoma. Cancer Lett 2013;336:222-230.

-46 Si W, Kang Q Luu HH, Park JK, Luo Q, Song WX, Jiang W, Luo X, Li X, Yin H, Montag AG, Haydon RC, He TC: Ccn1/cyr61 is regulated by the canonical wnt signal and plays an important role in wnt3a-induced osteoblast differentiation of mesenchymal stem cells. Mol Cell Biol 2006;26:2955-2964.

47 Haydon RC, Zhou L, Feng T, Breyer B, Cheng H, Jiang W, Ishikawa A, Peabody T, Montag A, Simon MA, He TC: Nuclear receptor agonists as potential differentiation therapy agents for human osteosarcoma. Clin Cancer Res 2002;8:1288-1294.

48 Luo Q, Kang Q, Si W, Jiang W, Park JK, Peng Y, Li X, Luu HH, Luo J, Montag AG, Haydon RC, He TC: Connective tissue growth factor (ctgf) is regulated by wnt and bone morphogenetic proteins signaling in osteoblast differentiation of mesenchymal stem cells. J Biol Chem 2004;279:55958-55968.

49 Peng Y, Kang Q, Luo Q Jiang W, Si W, Liu BA, Luu HH, Park JK, Li X, Luo J, Montag AG, Haydon RC, He TC: Inhibitor of DNA binding/differentiation helix-loop-helix proteins mediate bone morphogenetic proteininduced osteoblast differentiation of mesenchymal stem cells. J Biol Chem 2004;279:32941-32949.

50 Tang N, Song WX, Luo J, Luo X, Chen J, Sharff KA, Bi Y, He BC, Huang JY, Zhu GH, Su YX, Jiang W, Tang M, He Y, Wang Y, Chen L, Zuo GW, Shen J, Pan X, Reid RR, Luu HH, Haydon RC, He TC: Bmp9-induced osteogenic differentiation of mesenchymal progenitors requires functional canonical wnt/beta-catenin signaling. J Cel Mol Med 2009;13:2448-2464.

-51 Zhang W, Deng ZL, Chen L, Zuo GW, Luo Q Shi Q, Zhang BQ, Wagner ER, Rastegar F, Kim SH, Jiang W, Shen J, Huang E, Gao Y, Gao JL, Zhou JZ, Luo J, Huang J, Luo X, Bi Y, Su Y, Yang K, Liu H, Luu HH, Haydon RC, He TC, He BC: Retinoic acids potentiate bmp9-induced osteogenic differentiation of mesenchymal progenitor cells. PloS One 2010;5:e11917.

52 Chen L, Jiang W, Huang J, He BC, Zuo GW, Zhang W, Luo Q, Shi Q, Zhang BQ, Wagner ER, Luo J, Tang M, Wietholt C, Luo X, Bi Y, Su Y, Liu B, Kim SH, He CJ, Hu Y, Shen J, Rastegar F, Huang E, Gao Y, Gao JL, Zhou JZ, Reid RR, Luu HH, Haydon RC, He TC, Deng ZL: Insulin-like growth factor 2 (igf-2) potentiates bmp-9induced osteogenic differentiation and bone formation. J Bone Miner Res 2010;25:2447-2459.

-53 Wagner ER, Luther G, Zhu G, Luo Q, Shi Q, Kim SH, Gao JL, Huang E, Gao Y, Yang K, Wang L, Teven C, Luo X, Liu X, Li M, Hu N, Su Y, Bi Y, He BC, Tang N, Luo J, Chen L, Zuo G, Rames R, Haydon RC, Luu HH, He TC: Defective osteogenic differentiation in the development of osteosarcoma. Sarcoma 2011;2011:325238.

54 Fernandez-Fernandez MR, Rutherford TJ, Fersht AR: Members of the s100 family bind p53 in two distinct ways. Protein Sci 2008;17:1663-1670.

55 Santamaria-Kisiel L, Rintala-Dempsey AC, Shaw GS: Calcium-dependent and -independent interactions of the s100 protein family. Biochem J 2006;396:201-214.

-56 Fernandez-Fernandez MR, Veprintsev DB, Fersht AR: Proteins of the s100 family regulate the oligomerization of p53 tumor suppressor. Proc Nat Acad Sci USA 2005;102:4735-4740.

57 van Dieck J, Brandt T, Teufel DP, Veprintsev DB, Joerger AC, Fersht AR: Molecular basis of s100 proteins interacting with the p53 homologs p63 and p73. Oncogene 2010;29:2024-2035. 


\section{Cellular Physiology $\quad$ Cell Physiol Biochem 2013;32:1083-1096 and Biochemistry \\ Chen et al.: S100A4-Mediated Proliferation of Osteosarcoma}

-58 Grigorian M, Andresen S, Tulchinsky E, Kriajevska M, Carlberg C, Kruse C, Cohn M, Ambartsumian N, Christensen A, Selivanova G, Lukanidin E: Tumor suppressor p53 protein is a new target for the metastasis-associated mts1/s100a4 protein: Functional consequences of their interaction. J Biol Chem 2001;276:22699-22708.

59 Orre LM, Panizza E, Kaminskyy VO, Vernet E, Graslund T, Zhivotovsky B, Lehtio J: S100a4 interacts with p53 in the nucleus and promotes p53 degradation. Oncogene doi: 10.1038/onc.2013.213.

60 Zimmer DB, Wright Sadosky P, Weber DJ: Molecular mechanisms of s100-target protein interactions. Microsc Res Tech 2003;60:552-559.

-61 Bjornland K, Winberg JO, Odegaard OT, Hovig E, Loennechen T, Aasen AO, Fodstad O, Maelandsmo GM: S100a4 involvement in metastasis: Deregulation of matrix metalloproteinases and tissue inhibitors of matrix metalloproteinases in osteosarcoma cells transfected with an anti-s100a4 ribozyme. Cancer Res 1999;59:4702-4708.

62 Ma X, Yang Y, Wang Y, An G, Lv G: Small interfering rna-directed knockdown of s100a4 decreases proliferation and invasiveness of osteosarcoma cells. Cancer Lett 2011;299:171-181.

63 Aubin JE: Regulation of osteoblast formation and function. Rev Endocr Metab Disord 2001;2:81-94.

64 Luu HH, Song WX, Luo X, Manning D, Luo J, Deng ZL, Sharff KA, Montag AG, Haydon RC, He TC: Distinct roles of bone morphogenetic proteins in osteogenic differentiation of mesenchymal stem cells. J Orthop Res 2007;25:665-677.

65 Luther G, Wagner ER, Zhu G, Kang Q, Luo Q, Lamplot J, Bi Y, Luo X, Luo J, Teven C, Shi Q, Kim SH, Gao JL, Huang E, Yang K, Rames R, Liu X, Li M, Hu N, Liu H, Su Y, Chen L, He BC, Zuo GW, Deng ZL, Reid RR, Luu HH, Haydon RC, He TC: Bmp-9 induced osteogenic differentiation of mesenchymal stem cells: Molecular mechanism and therapeutic potentia. Curr Gene Ther 2011;11:229-240.

66 Lamplot JD, Qin J, Nan G, Wang J, Liu X, Yin L, Tomal J, Li R, Shui W, Zhang H, Kim SH, Zhang W, Zhang J, Kong Y, Denduluri S, Rogers MR, Pratt A, Haydon RC, Luu HH, Angeles J, Shi LL, He TC: Bmp9 signaling in stem cell differentiation and osteogenesis. Am J Stem Cells 2013;2:1-21.

67 He TC: Distinct osteogenic activity of bmps and their orthopaedic applications. J Musculoskelet Neuronal Interact 2005;5:363-366.

68 Lengner CJ, Steinman HA, Gagnon J, Smith TW, Henderson JE, Kream BE, Stein GS, Lian JB, Jones SN: Osteoblast differentiation and skeletal development are regulated by mdm2-p53 signaling. J Cell Biol 2006;172:909-921. 